Journal of Qualitative Criminal Justice \& Criminology

\title{
Historical Book Review | Outsiders: Studies in the Sociology of Deviance
}

Kenneth D. TunnelI ${ }^{1}$

${ }^{1}$ Eastern Kentucky University

Published on: Apr 01, 2014

Updated on: Aug 02, 2020

DOI: $10.21428 / 88 \mathrm{de} 04 \mathrm{a} 1.0 \mathrm{cbb} 4 \mathrm{a} 84$

License: Creative Commons Attribution 4.0 International License(CC-BY 4.0). 
Howard S. Becker. Outsiders: Studies in the Sociology of Deviance. The Free Press, 1963; 215 pp.; ISBN: 0684836351.

While recently reviewing a manuscript submission for a sociology journal and noticing Becker's (1963) appearance in the body of the text, I discovered, when skimming the references, that the citation read "The Outsiders." I remember wondering just how familiar the authors may have been with Outsiders or if they had actually read it-given that they got the title wrong. After all, Outsiders has become one of those books that simply must be cited. And, with growing interest among younger scholars in field research, deviant groups, cultural criminology and inductive analysis, Outsiders has become symbolic of good work that must be recognized, deferred to, mentioned if only in passing, and cited regardless of one's familiarity with it. It's Outsiders after all and it simply must be included, so goes the reasoning. I do believe it is necessary and not sacrilege to question today, in 2014, the relevance of a book that is more than 50 years old and whose research for it nearly 60 years old. At one time required reading in courses in the sociology of deviance, social problems and criminology, Outsiders likely has fallen out of favor as newer and more contemporary literature takes its place. The same is likely the case with Mills' (1959) The Sociological Imagination, another required read by countless university students and often cited by young scholars. Yet today, it and Outsiders more than likely go unread.

After recently re-reading The Sociological Imagination and more recently Outsiders, it is obvious that these are books of their time. It is noticeable in the language, the examples used and the issues of the day. As a result, there is much in those books that locates them and their significance in a previous epoch. The most obvious example found in Mills is the consistent reference to man and men and the consistent exclusion of anything to do with woman or women. Outsiders' historical location is most obvious in reference to race and sexual behavior and orientation. For example, an unmarried pregnant woman is likely to experience "severe" reactions from others; an Italian-American doctor finds it difficult to gain acceptance among non-Italians; people expect medical doctors to be white, middleclass and Protestant; the difficulties encountered by and the full-blown ideologies constructed among deviants, such as homosexuals and drug users. These are the examples that most appear within the pages of Outsiders. This is not a criticism per se as readers can easily replace $\mathrm{X}$ for $\mathrm{Y}$ in each of the examples. Rather, this illustrates that the book, this classic book, like most, emerges from and is forever located within its own social and historical period.

Yet, there is no denying the vast importance that both Becker and Mills have had on the sociological universe. They are hugely important in the sociological canon. While others have addressed the significance of Mills' classic work, the historical significance and place of Outsiders is the aim of this review. But first, a bit of biography. 
Howard Saul Becker was born on April 18, 1928, on the west side of Chicago, the city that would remain his home throughout his university education (and beyond). At age 15, he began a career as a professional pianist and performed in bars and taverns during much of his younger years (and until the early 1970s) (Becker, 1963, p. 84; Martin, Mutchnick, \& Austin, 1990, p. 349).

The "Acknowledgments" in Outsiders reveals some important biographical history of the book, the piecemeal process by which it took shape and Becker's formal education. Four of the book's chapters had been published prior to 1963. The two chapters on marihuana use (the spelling used by Becker) were written as part of Becker's master's thesis (University of Chicago, 1949) and appeared in 1953 in the American Journal of Sociology. The two chapters on dance musicians first appeared in sociology journals in 1951 and 1955. Becker completed his Ph.D. in 1951 under the direction of Everett C. Hughes at the University of Chicago. The first draft of Outsiders was completed in 1954 but at only 90 pages in length, was too short for a suitable monograph. As shockingly unimaginable as it may seem today, the original draft of Outsiders did not contain the four chapters on marihuana use and dance musicians. After including those four chapters the book was published in 1963 by The Free Press (Martin, Mutchnick, \& Austin, 1990, p. 352). Today, a safe bet is that Outsiders is best known for those four chapters on marihuana and musicians rather than chapters from the 1954 version. For me, they have been and remain the most important parts of the book as they are instructive about field research and are immensely insightful as they well represent (using interview dialogue and participant observation) marihuana users and musicians. The point of field research is to accurately represent. Becker clearly embraced that commitment as we learn intimately about those two groups' social worlds.

After Becker's graduate days ended, he went to work for Everett Hughes researching medical school culture and then undergraduate student experiences, both at the University of Kansas, resulting in two books based on their field experience (Boys in White and Making the Grade). In 1965 Becker returned to his native Chicago taking a position at Northwestern University where he remained until his retirement in 1991. He then moved to the University of Washington where he worked until his second retirement in 1999.

Now, to the substance of this review. Everett C. Hughes was a major influence on Becker as was the work of Alfred R. Lindesmith (1947). But, glaringly absent from Outsiders is any mention of Edwin Sutherland's differential association approach (other work by Sutherland, such as The Professional Thief and "White Collar Criminality" is cited). Sutherland's differential association approach first appeared in 1939 and was published in revised form in 1947, two years before Becker completed his master's thesis. Although there is much in Outsiders that sounds like Sutherland and arguably owed to him, no mention is made of his now-classic work which many consider "one of the best known and 
most systematic and influential of the interpersonal theories" (Martin et al., 1990, p. 155). Consider this passage from Outsiders:

... when one moves into a deviant group... he learns how to carry on his deviant activity with a minimum of trouble. All the problems he faces in evading enforcement of the rule he is breaking have been faced before by others. Solutions have been worked out. Thus, the young thief meets older thieves who, more experienced than he is, explain to him how to get rid of stolen merchandise without running the risk of being caught. Every deviant group has a great stock of lore on such subjects and the new recruit learns it quickly. (Becker, 1963, p. 39)

Sounds like Sutherland to me. Yet, there is no mention.

Juxtapose Becker's omission of acknowledging Sutherland with Sam Wallace's Skid Row as a way of Life (1965) where he states emphatically the debt owed to Becker's Outsiders. From Wallace's (1965, p. 165) field research he understood and then wrote eloquently about the sequential process of becoming homeless: "Howard Becker's recent publication had a significant influence on my own work, an influence which is most gratefully acknowledged." Twenty years later, that giant of a thinker, Bill Chambliss (1988, p. 276), wrote that Outsiders was "an extraordinarily influential book." As much as those who came after Becker admit their indebtedness to him, his lack of doing likewise with some who came before seems an unusual omission and lacks a historical positioning in the process of intellectual thought. Apart from these thoughts, I have no further criticism of this vastly important and classic work.

Those considered "Outsiders," for Becker (1963, p. 1) take two distinct forms as is illustrated in his prose:

When a rule is enforced, the person who is supposed to have broken it may be seen as a special kind of person, one who cannot be trusted to live by the rules agreed on by the group. He is regarded as an outsider. But the person who is thus labeled an outsider may have a different view of the matter. He may not accept the rule by which he is being judged and may not regard those who judge him as either competent or legitimately entitled to do so. Hence, a second meaning of the term emerges: the rule breaker may feel his judges are outsiders.

We see in this succinct quotation the dynamics of labeling, its subjectivity, fluidity and power. A good friend recently visited New York City. While riding in a taxi, she witnessed but could not quite hear another animated taxi driver say something to her driver. In the next moment her driver quickly lowered his window and shouted to the other, "No, you da fuckin' asshole." And the effort to label goes back and forth each claiming (and loudly) that the other is deviant, beyond the rules and etiquette of the road and the outsider. 
Labeling, for Becker, does not result from a universal consensus on rules but rather from conflict. For those who make the rules and yet are labeled as outsiders by others are those who engage in moral crusades. They are who Becker defines as moral entrepreneurs.

Society creates deviance, so says Becker, but not in sort of causal or criminogenic character. Rather, "social groups create deviance by making the rules whose infraction constitutes deviance, and by applying those rules to particular people and labeling them as outsiders. ... The deviant is one to whom that label has successfully been applied; deviant behavior is behavior that people so label" (1963, p. 9, emphasis in original). It is the response that matters for without it, deviant behavior has not occurred. The response is variable. There is variation over space and time in rules and in peoples' reactions to their violation. There is variation based on the actor and victim as rules are applied more to some people than others and in response to the victimization of some rather than others. And there is variation in rule application due to the consequences of an act-as some consequences are graver than others. In writing about such variance, Becker intends to make clear that deviance is not simply a quality present in some and not in others. It is not static. Rather it is "the product of a process which involves responses of other people to the behavior. The same behavior may be an infraction of the rules at one time and not at another; may be an infraction when committed by one person, but not when committed by another; some rules are broken with impunity, others are not" (Becker, 1963, p. 14). Only a few short years later, American folk song singer-songwriter and sometimes public spokesman for the incarcerated, Johnny Cash, wrote of the shifting definitions of crime and of those punished for engaging in behaviors whose criminal definitions are far from static (Cash, 1971; Tunnell \& Hamm, 2009):

I wear the black for the poor and the beaten down

Livin' in the hopeless, hungry side of town,

I wear it for the prisoner who has long paid for his

crime But is there because he's a victim of the times.

Little did Cash know but he was preaching a text straight out of Outsiders.

My friend, a retired public defender who successfully kept many a man off of death row tells of his experiences. Late at night the telephone would ring and he would receive news of a murder and that the accused was in need of his services. The first question out of his mouth was "Who's the victim?" for he knew the answer set into motion everything about the social response. Social response is variable and in this instance based on the victim. Becker was absolutely right and saw into the future as today it has been determined empirically that the victim's race is a central variable in determining the social and legal response (e.g., Paternoster 1991, Chapter 4). 
Becker (1963, p. 31) realized that the labeling process is a significant phenomenon in the pathway of deviant careers. In order to establish a stable pattern of deviant behavior one typically experiences being found out, caught and then labeled. Being caught and successfully labeled as deviant has consequences for future behavior, self-image and public identity. Once labeled the person's identity becomes fundamentally different from others and from the type of person she/he was expected to be. Crediting his mentor Everett C. Hughes (1945), Becker makes use of Hughes' notions of "master and subordinate statuses" or traits:

To be labeled a criminal one need only commit a single criminal offense ... Some statuses, in our society as in others, override all other statuses ... One receives the status as a result of breaking a rule, and the identification proves to be more important than most others. One will be identified as a deviant first, before other identifications are made ...Treating a person as though he were generally rather than specifically deviant produces a self-fulfilling prophecy. It sets in motion several mechanisms which conspire to shape the person in the image people have of him. (Becker, 1963, p. 33)

I'm reminded of a joke about a pig ...

The self-fulfilling prophecy sets into motion a variety of mechanisms. For example, those successfully labeled deviant may find themselves isolated from more conventional groups, not necessarily because of the deviance but because of the response. One may have difficulty at their place of employment or in locating employment. There may be trouble in participating in the mundane and ordinary routines of life that are easily accessible to those not labeled (but who may be participating in deviant activities). Denied easy access to ordinary and conventional aspects of social life, illegitimate routines may develop. Deviance may become a sequential process and ultimately a career. Years ago, while talking with an ex-con, he expressed these very notions, just not in a theoretical sort of rhetoric:

I tried to find [a job]. But when you commit the crime, you commit it and you get sentenced to pay a debt to society. But that debt's never paid. You cannot pay that debt. You're screwed the rest of your life (Tunnell, 1992, p. 57).

Stand out portions of Outsiders are the marihuana use and dance musicians chapters; the stuff of legend. Those four chapters are as relevant today as they were when Becker was engaged in the research (ca. late 1940s and early 1950s). The first of those chapters is titled "Becoming a Marihuana User." Becoming. What a perfect word choice. The process by which one becomes something, anything, is the stuff of symbolic interactionism. Becker, rejecting psychological explanations for marihuana use, describes the socialpsychological process of learning techniques of smoking (and acquiring the illicit drug) and learning to define it and its effects as pleasurable. Although Sutherland's name is absent, this is process that Sutherland describes - informally learning techniques and definitions within the 
context of intimate groups. Tracing the "sequence of changes," Becker describes the transition from novice to career user that he gleaned from his field research and interviews with users or former users. As he instructs, some do not find the drug enjoyable. "Enjoyment is introduced by the favorable definitions of the experience that one acquires from others" (Becker, 1963, p. 56). We see as we do in Sutherland's work that the learning of techniques and definitions is a social and not psychological phenomenon.

As pointed out earlier, “... the rule breaker may feel his judges are outsiders” (Becker, 1963, p. 1). Such is the case with the dance musicians described from Becker's participant observation research during late 1940s Chicago (Becker also performed and kept field notes on his experiences in Champaign, Illinois and Kansas City, Missouri). The musicians, members of an in-group, define non-members as outsiders and more pejoratively as squares. The musicians define themselves as autonomous and reject interference in their craft from anyone, insiders and especially outsiders. Given that the square outsider is the paying customer as well as the person who has hired the musicians for a performance, conflict emerges. The musicians, determined to maintain their independence yet recognizing who is paying the bills, are swirling within a conflicting situation. Maintaining a professional distance from outsiders yet pleasing the paying customer is a tightrope act. Some, according to Becker, handle it better than others. Maintaining some distance or professional separation from the audience inhibits direct interference from the customer and allows musicians to perform the material of their choosing without sacrificing professional standards. Raised stages allow for this but in the absence of such, musicians are left to construct temporary blockades which, for the most part, do not prevent outsiders' interference on their craft. Given musicians' rejection of conventionalism and the awkward relationship with their audience, conflict is implicit in such social relations. When Becker asked one musician what he thought of the audience he responded:

They're a drag. If you're working on a commercial band, they like it and so you have to play more corn. If you're working on a good band, then they don't like it, and that's a drag. If you're working on a good band and they like it, then that's a drag, too. You hate them anyway, because you know that they don't know what it's all about. They're just a big drag. (Becker, 1963, p. 91)

Neutralization is also key to Becker's descriptions of deviant careers (whether marihuana user, dance musician or other type of deviant). One must neutralize the commonly-held stereotypes of the deviant and develop alternative interpretations of their activities. Recognizing the work of Sykes and Matza (1957), Becker shows that such neutralization is necessary for a sustained deviant career.

Across the pages of Outsiders Becker is adamant about the need for good field research. Deviant activity, he writes, is for the most part kept hidden from outsiders. Anyone interested in learning about activities and subcultures and where they are found must spend time in the field convincing and explaining, all the while trying to gain access. "The researcher, therefore, must participate intensively 
and continuously with the deviants he wants to study so that they will get to know him well enough to be able to make some assessment of whether his activities will adversely affect theirs" (Becker, 1963, p. 168). This is not fly-over sociology.

Now, in the second decade of the 21st century, the obvious inheritor of Becker's primary theses is cultural criminology. Cultural criminology has embraced many of the themes found in Outsiders. Of course, cultural criminology does not hold a monopoly on such but today represents the single most important and vast school of thought representing those areas of contemporary relevance found within the pages of Outsiders. The listing below are those key issues relevant to Outsiders and that are thriving within the many styles of cultural criminology (Ferrell, Hayward, \& Young, 2008):

- A rejection of positivism and determinism

- A philosophy of science that attempts to explain the subjectivity of human behavior

- A focused interest in collective behavior or finding, as Becker (1986) described, "where the action is" and where people are doing things together

- Symbolic interactionism

- Meanings and definitions and the processes by which they

- take shape within human activity

- The social reactions and labeling of actors

- The shifting definitions of deviance and crime

- Field research, participant observation and interviewing as key research methods

Although some readers treat Becker's work as a theory, he consistently has dismissed any notion that his ideas about labeling constitute theory. But, if readers insist and if that term must be used, he prefers that it be considered an interactionist theory of deviance. Today, more than 50 years after the publication of Outsiders, Becker evidently is asked (by e-mail) to explain his work or to help students understand his "labeling theory." From his website, Becker attempts to stem the flow of requests:

- I said everything I have to say about labeling theory in my book, Outsiders. This book is available in most university and college libraries and is almost certainly in your library if your teacher has told you to write about it ... I have nothing to add to what I said in that book. I'm not a criminologist, although you may have gotten this assignment in a criminology class, and have not worked in this field for a very long time. Other people have written about it, but I don't keep track of that and cannot give you a bibliography ...

In other words, go forth and do the research yourselves, as Outsiders instructs. 1

\section{References}

Becker, H. S. (1963). Outsiders: Studies in the sociology of deviance. New York, NY: The Free Press. 
Becker, H. S. (1986). Doing things together: Selected papers. Evanston, IL: Northwestern University Press.

Becker, H. S. [Personal web site]. Retrieved from http://home.earthlink. net/ hsbecker/

Becker, H. S., Geer, B., Hughes, E. C., \& Strauss, A. L. (1961). Boys in white: Student culture in medical school. Chicago: University of Chicago Press.

Becker, H. S., Geer, B., \& Hughes, E. C. (1968). Making the grade: The academic side of college life. New York, NY: Wiley \& Sons.

Cash, J. (1971). Man in black. On Man in black [CD]. USA: Columbia Records. Chambliss, W. J. (1988). exploring criminology. New York, NY: Macmillan.

Ferrell, J., Hayward, K. \& Young, J. (2008). Cultural criminology: An invitation. London, England: Sage.

Hughes, E. C. (1945). Dilemmas and contradictions of status. American Journal of Sociology, 50, 353-359.

Lindesmith, A R. (1947). Opiate addiction. Bloomington, IN: Principia Press. Martin, R., Mutchnick, R. J., \& Austin, W. T. (1990). Criminological thought: Pioneers past and present. New York, NY: Macmillan.

Mills, C. W. (1959). The sociological imagination. New York, NY: Oxford University Press.

Paternoster, Raymond. (1991). Capital punishment in America. New York, NY: Lexington Books.

Sutherland, E. H. (1937). The professional thief. Chicago, IL: University of Chicago Press.

Sutherland, E. H. (1939). Principles of criminology (3rd ed.). Philadelphia, PA: J.B. Lippincott Company.

Sutherland, E. H. (1940). White collar criminality. American Sociological Review, 5, 1-12.

Sutherland, E. H. (1947). Principles of criminology (4th ed.). Philadelphia, PA: J.B. Lippincott Company.

Sykes, G. M. \& Matza, D. (1957). Techniques of neutralization: A theory of delinquency. American Sociological Review, 22, 664-670.

Tunnell, K. D. (1992). Choosing crime. Chicago, IL: Nelson-Hall.

Tunnell, K. D. \& Hamm, M. S. (2009). Singing across the scars of wrong: Johnny Cash and his struggle for social justice. Crime Media Culture, 5, 268-284.

Wallace, S. E. (1965). Skid Row as a way of life. Totowa, NJ: The Bedminster Press. 


\section{Footnotes}

1. For one of the best descriptions of Becker's body of work, its theoretical and methodological assumptions, key ideas, social and historical emergence and critique, readers are referred to Martin et al. (1990), Chapter 14.. 